medRxiv preprint doi: https://doi.org/10.1101/2021.12.06.21266950; this version posted December 8, 2021. The copyright holder for this preprint (which was not certified by peer review) is the author/funder, who has granted medRxiv a license to display the preprint in

It is made available under a CC-BY-NC-ND 4.0 International license.

\title{
Survival and outcomes of tocilizumab use in severe and critically ill Covid-19 patients not responding to steroids
}

Dr Shiraz Assu*, Dr Deepak Bhasin*,Dr Kavita Sekhri^ ,Dr Supriya Sampley*, Dr Harpal Singh*, Dr Gurleen Kaur*

*Max Super Specialty Hospital, Mohali, Punjab, India

${ }^{\wedge}$ Dr. Harvansh Singh Judge Institute of Dental Sciences \& Hospital, Chandigarh,India

\section{$\underline{\text { Abstract }}$}

\section{Background}

Mortality and morbidity are highest in severe and critically ill patients with COVID -19 pneumonia. Recently corticosteroids have shown a definite mortality benefit in these patients. In this study we used interleukin -6 inhibitor, tocilizumab in patients who failed to show any clinical improvement after initial treatment with steroids.

\section{Patients and methods}

This is a retrospective observational study conducted at a tertiary care referral hospital in India. Severe and critical COVID 19 patients, who got admitted to intensive care unit and subsequently received tocilizumab were included. Patients who worsened clinically or had no change in oxygen requirement even after $24 \mathrm{hrs}$ of receiving Intravenous methylprednisolone at a dose of $1-2 \mathrm{mg} / \mathrm{kg} /$ day received a maximum total dose of $800 \mathrm{mg}$ of intravenous tocilizumab. The day 28 all cause mortality and progression to mechanical ventilation were the primary outcome measures. Clinical improvement and oxygen requirements after tocilizumab administration along with trends in inflammatory markers were secondary outcome. Secondary infections rates and other drug related side effects were also noted.

\section{Results}

A total of 51 patients who did not show clinical improvement even after 24 hours of intravenous steroids and received tocilizumab were included. In these patients, there was a significant decrease in oxygen requirement by day 3 and clinical improvement by day 7 of tocilizumab administration. Among the inflammatory markers, we observed elevated median baseline values of CRP $(114.2 \mathrm{mg} / \mathrm{L})$, IL-6 $(55.4 \mathrm{pg} / \mathrm{ml})$ and Neutrophil to Lymphocyte Ratio (12.4). Out of these only CRP showed a significant decrease after the drug administration. $13(26.5 \%)$ of the 49 patients who were on non-invasive or conventional oxygen support progressed to mechanical ventilation. The day 28 all-cause mortality rate was NoTE: This preprint reports new research that has not been certfied by peer review life thre should not bening used infectionions cinical practice. 
5/51 had thrombocytopenia, 3/51 had pneumomediastenum/pneumothorax, 1 patient had colonic perforation and 1 patient had transaminitis following tocilizumab administration.

\section{Conclusion}

Early and timely administration of tocilizumab only in selected severe and critical covid patients not responding to initial steroids appears to increase the survival. Further randomized controlled trials are required to confirm this finding. 


\section{Manuscript}

\section{Introduction}

A novel corona virus was first detected in Wuhan, in Hubei Province of China in late 2019. ${ }^{[1]}$ In February 2020, it was assigned the name COVID19 by World Health Organization and on March 11th it was declared a pandemic. The corona virus study group of the International Committee on Taxonomy of Viruses (ICTV) has named it Severe Acute Respiratory Syndrome Corona virus 2 (SARS-COV-2). ${ }^{[2]}$ In spite of all the necessary measures taken to halt this emerging virus, it has spread worldwide.$^{[3]}$ Due to pandemic and associated mortality, astronomical efforts are going on to discover molecules which effective against SARS-CoV-2. But even after more than one year of pandemic, wide scale research is still underway to reach a consensus regarding the perfect treatment protocol, which could significantly decrease the morbidity \& mortality. One of the main reason behind this may be the unpredictability of the disease progression.

In view of the studied Covid immuno-pathogenesis, which showed the role of heightened cytokine release in COVID-19 associated systemic inflammation and hypoxic respiratory failure ${ }^{[1,4,5]}$, many drugs altering these mechanisms have been tried as treatment. Among these, till date corticosteroids are the only medications that have shown to improve survival ${ }^{[6-9]}$.This may be due to their broad spectrum anti-inflammatory effects. Another group which is being increasingly recognized are the immune modulators like monoclonal antibodies against interleukin 6(IL6) receptors, interleukin 1(IL1),CD6 etc .One of the most commonly studied and used drug among them is tocilizumab which inhibits the binding of IL6 to both membrane and soluble IL6 receptors. IL-6 is a pleotropic cytokine released in response to infection and stimulates inflammatory pathways as a part of the acute phase response. IL-6 inhibitors are currently being used as an anti-inflammatory agent in many conditions like rheumatoid arthritis, cytokine release syndrome due to chimeric antigen receptor T-cell therapy or giant cell arteritis. Infection by the severe acute respiratory syndromeassociated coronavirus (SARS-CoV) induces a dose-dependent production of IL-6 from bronchial epithelial cells. ${ }^{[10]}$

Few recent trials have shown good results with the use of Tocilizumab in COVID 19.Based on these results, on June 26,2021 the FDA issued an Emergency Use Authorization(EUA) for Tocilizumab, for the treatment of 
medRxiv preprint doi: https://doi.org/10.1101/2021.12.06.21266950; this version posted December 8, 2021. The copyright holder for this preprint (which was not certified by peer review) is the author/funder, who has granted medRxiv a license to display the preprint in It is made available under a CC-BY-NC-ND 4.0 International license .

hospitalised adults band paediatric patients ( $>2$ years) requiring supplemental oxygen. But in such patients, its timing of administration, dosage and effects are still unclear, especially when given in combination with corticosteroids.

We in our hospital administered tocilizumab timely in all those patients who were not clinically responding to steroids and we hypothesise that this approach increased the survival of severe and critically ill Covid patients admitted to the ICU. Because of the pandemic situation during the study period, getting a control group was not possible. Hence we plan to compare our outcomes with those described in literature, where tocilizumab was administered to all severe or critical patients irrespective of their response to steroids.

For this we conducted a retrospective single center observational study on all severe and critical Covid 19 patients, who were admitted in our ICU and received tocilizumab.

\section{Materials and Methods}

\section{Design and setting}

We performed a retrospective study at a tertiary care hospital in Northern India. In view of the pure retrospective nature of the study, informed consent was waivered.

Hospital electronic medical records were reviewed from April 2020 to February 2021. All consecutive adult ( $>18$ years) patients confirmed as COVID-19 by reverse-transcription polymerase chain reaction assay or rapid antigen-positive test and admitted to the ICU with severe and critical disease( as defined by WHO- table 1) without evidence of sepsis, and treated with tocilizumab were eligible for inclusion. The decision to administer tocilizumab was based on clinical worsening or lack of improvement in oxygen requirement even after $>24 \mathrm{hrs}$ of receiving IV methylprednisolone at a dose of $1-2 \mathrm{mg} / \mathrm{kg} /$ day, irrespective of the levels of various inflammatory markers. Patients were administered the drug only in the pulmonary or early hyper inflammatory phase (5-20 days from symptom onset) of the disease. ${ }^{[11]}$ The clinical status of the patients upto day 28 of tocilizumab administration was observed for the outcome measures.

Tocilizumab was not given to patients with known hypersensitivity to tocilizumab or any of their excipients, condition or treatment resulting in ongoing immunosuppression including neutropenia, known or suspected 
medRxiv preprint doi: https://doi.org/10.1101/2021.12.06.21266950; this version posted December 8, 2021. The copyright holder for this preprint (which was not certified by peer review) is the author/funder, who has granted medRxiv a license to display the preprint in It is made available under a CC-BY-NC-ND 4.0 International license .

pregnancy, current evidence of any bacterial, fungal or other viral infections, previous history of tuberculosis, and patients with any of following laboratory results out of the ranges, as detailed below at screening.

a) Absolute neutrophil count (ANC) $\leq 1.0 \times 10^{9} / \mathrm{L}$, b) Platelets (PLT) $<50$ x $\left.10^{9} / \mathrm{L}, \mathrm{c}\right)$ SGOT or SGPT > 5x upper normal limit.

\section{$\underline{\text { Standard treatment }}$}

The management of the patients in severe and critical category included steroids ( $1-2 \mathrm{mg} / \mathrm{kg} /$ day of methylprednisolone) for 7-10 days followed by tapering doses, Injection remdesivir $200 \mathrm{mg}$ on day 1 , followed by $100 \mathrm{mg}$ once daily for 4 days and other supportive management such as low molecular weight heparin. The patients with acute hypoxemic respiratory failure (AHRF) were given a trial of high flow nasal canula (HFNC) and/or noninvasive ventilation (NIV) in ICU to achieve SpO2 of 88-93\%, if there was no contraindication.

The indications for tracheal intubation were:

- Rapid progression of hypoxemia over hours.

- Signs of respiratory fatigue (excessive use of accessory muscles of breathing, hypercarbia (pCO2 more than $45 \mathrm{~mm} \mathrm{Hg}$ ), and/or altered mental status.

- Unable to maintain oxygen saturation (SpO2) $>88 \%$ on HFNC with a flow of $60 \mathrm{~L} /$ minute and $\mathrm{FiO} 2 \geq 90 \%$

- Unable to maintain $\mathrm{SpO} 2>88 \%$ on NIV with $\mathrm{FiO} 2 \geq 90 \%$ and/or persistent use of NIV for more $\geq 48$ hours.

- Hemodynamic instability.

Drug administration

Tocilizumab was given at a dose of $400 \mathrm{mg}$ intravenously as an infusion over 1 hour, followed by a second dose of up to 400mg (maximum total dose of $800 \mathrm{mg}$ ) within 24 hours if there was no significant clinical improvement.

Along with this all the patients also received standard treatment which included steroids (1-2mg/kg of methylprednisolone), antivirals (remdisivir $200 \mathrm{mg}$ on day 1 and $100 \mathrm{mg}$ from day 2 to day 5), antibiotics at the discretion of the treating physician, prophylactic dose of low molecular weight heparin and other supportive management.

If not tolerating conventional oxygen support via nasal prongs or face mask , patients were given given a trial of high flow nasal canula (HFNC) and/or 
medRxiv preprint doi: https://doi.org/10.1101/2021.12.06.21266950; this version posted December 8, 2021. The copyright holder for this preprint (which was not certified by peer review) is the author/funder, who has granted medRxiv a license to display the preprint in

It is made available under a CC-BY-NC-ND 4.0 International license .

noninvasive ventilation (NIV) in ICU to achieve $\mathrm{SpO} 2$ of $88-93 \%$, if there was no contraindication. Patients were intubated and put on invasive ventilation, based on the following indications:

- Rapid progression of hypoxemia over hours.

- Unable to maintain oxygen saturation $(\mathrm{SpO} 2)>88 \%$ on HFNC with a flow of $60 \mathrm{~L} /$ minute and $\mathrm{FiO} 2 \geq 90 \%$

- Unable to maintain $\mathrm{SpO} 2>88 \%$ on NIV with $\mathrm{FiO} 2 \geq 90 \%$ and/or persistent use of NIV for more $\geq 48$ hours.

- Signs of respiratory fatigue (excessive use of accessory muscles of breathing), hypercarbia (pCO2 more than $45 \mathrm{~mm} \mathrm{Hg}$ ), and/or altered mental status)

Hemodynamic instability.

- Psychomotor agitation making nursing care impossible and requiring sedation.

\section{Outcome measures}

The primary outcome were the incidence of progression to invasive mechanical ventilation and all-cause mortality at day 28 .

The secondary outcome measures were clinical improvement (assessed using WHO ordinal scale for disease progression), change in oxygen requirements and inflammatory markers (CRP, D-dimer, ferritin and neutrophil-lymphocyte ratio) after tocilizumab administration .Life threatening infections rates and other drug related side effects were also noted.

Table 1 -WHO Severity definitions

Critical COVID-19: Defined by the criteria for acute respiratory distress syndrome (ARDS), sepsis, septic shock, or other conditions that would normally require the provision of life sustaining therapies such as mechanical ventilation (invasive or noninvasive) or vasopressor therapy.

Severe COVID-19: Defined by any of:

Oxygen saturation $<90 \%$ on room air.

Respiratory rate $>30$ breaths/min.

Signs of severe respiratory distress (accessory muscle use, inability to complete full sentences)

Table 2 WHO Clinical Progression score

\begin{tabular}{|l|l|l|}
\hline $\begin{array}{l}\text { Clinical progression } \\
\text { scale }\end{array}$ & Descriptor & Score \\
\hline
\end{tabular}


medRxiv preprint doi: https://doi.org/10.1101/2021.12.06.21266950; this version posted December 8, 2021. The copyright holder for this preprint (which was not certified by peer review) is the author/funder, who has granted medRxiv a license to display the preprint in It is made available under a CC-BY-NC-ND 4.0 International license .

\begin{tabular}{|l|l|l|}
\hline Uninfected & Uninfected & 0 \\
\hline Ambulatory & Asymptomatic, Infected & 1 \\
\hline Ambulatory & Symptomatic and independent & 2 \\
\hline Ambulatory & Symptomatic and Assistance needed & 3 \\
\hline Hospitalized, mild disease & Hospitalized, No oxygen therapy & 4 \\
\hline Hospitalized, mild disease & $\begin{array}{l}\text { Hospitalized, Oxygen by nasal prongs or } \\
\text { face mask }\end{array}$ & 5 \\
\hline $\begin{array}{l}\text { Hospitalized, moderate } \\
\text { disease }\end{array}$ & $\begin{array}{l}\text { Hospitalized, Oxygen by high flow nasal } \\
\text { cannula or NIV }\end{array}$ & 6 \\
\hline $\begin{array}{l}\text { Hospitalized, moderate } \\
\text { disease }\end{array}$ & $\begin{array}{l}\text { Intubation and mechanical ventilation, } \\
\text { pO2/FIO2>=150 }\end{array}$ & 7 \\
\hline $\begin{array}{l}\text { Hospitalized, Severe } \\
\text { disease }\end{array}$ & $\begin{array}{l}\text { Intubation and mechanical ventilation , } \\
\text { pO2/FIO2 <=150 or vasopressor support }\end{array}$ & 8 \\
\hline $\begin{array}{l}\text { Hospitalized, Severe } \\
\text { disease }\end{array}$ & $\begin{array}{l}\text { Intubation and mechanical ventilation, } \\
\text { pO2/FIO2 <=150 and vasopressors or } \\
\text { Dialysis or ECMO }\end{array}$ & 9 \\
\hline Dead & Death & 10 \\
\hline
\end{tabular}

\section{$\underline{\text { Statistical Analysis }}$}

Considering a $20 \%$ decrease in all cause mortality, as compared to those described in previous studies on critically ill covid patients ${ }^{[12]}$, our sample size came out to be 49 subjects at a power of $90 \%$ \& confidence interval of $95 \%$. For possible attrition, it was decided to include 55 successive patients satisfying the inclusion criteria during the period of study.

All statistical analysis was done using SPSS software version 22. The required sample size was calculated as 55 considering $20 \%$ decrease from literature described mortality rates in ICU patients who were administered tocilizumab. The descriptive statistics were reported as mean, standard deviation, median, ranges and percentage/proportion etc. Wilcoxon-signed rank test was used to compare the non-normal quantitative values while chi-square/Fisher's exact test was applied for association between categorical variables. All comparative tests were 2 tailed, and a $p$ value of less than 0.05 was considered to be statistically significant.

\section{Results}

A total of $n=55$ patients who did not show clinical improvement even after 24 hours of intravenous steroids were administered tocilizumab. Out of this 4 patients were excluded as they were shifted to other medical facility before day 28 or primary outcome. Hence further $n=51$ patients were included in the study. The mean age of the patients was 58(33-80) years, out of which $80 \%$ were males and $20 \%$ were females. The mean Body Mass Index (BMI) of the patients was $29 \mathrm{~kg} / \mathrm{m}^{2}$ with a majority of $41(80.4 \%)$ being overweight. Fever $(86.3 \%)$ and cough $(84.3 \%)$ were the most common symptoms, whereas hypertension (62.7\%) followed by 
medRxiv preprint doi: https://doi.org/10.1101/2021.12.06.21266950; this version posted December 8, 2021. The copyright holder for this preprint (which was not certified by peer review) is the author/funder, who has granted medRxiv a license to display the preprint in It is made available under a CC-BY-NC-ND 4.0 International license .

diabetes $(58.8 \%)$ were the most common associated co-morbidities. The baseline characteristics of these patients are given in table 1.

Table 1 Baseline demographics

\begin{tabular}{|c|c|}
\hline Age & $58(33-80)$ \\
\hline Sex & $\begin{array}{l}\text { Male }-41(80 \%) \\
\text { Female }-10(20 \%)\end{array}$ \\
\hline $\mathrm{BMI}(\mathrm{kg} / \mathrm{m} 2)$ & $29 \pm 6(19.3-50.41)$ \\
\hline Symptoms & $\begin{array}{l}\text { Fever- } 44 \\
\text { Cough - } 43 \\
\text { Shortness of breath - } 35 \\
\text { Myalgia - } 9 \\
\text { Sore throat- } 5 \\
\text { Diarrhea - } 4 \\
\text { Vomiting- } 3 \\
\text { Abdominal pain - } 2 \\
\text { Oliguria -2 }\end{array}$ \\
\hline $\begin{array}{l}\text { Co-morbidities } \\
\text { Hypertension } \\
\text { Diabetes } \\
\text { Coronary artery disease } \\
\text { Chronic lung disease } \\
\text { Chronic kidney disease } \\
\text { Hypothyroid } \\
\text { Others* }\end{array}$ & $\begin{array}{l}32(62.7 \%) \\
30(58.8 \%) \\
11(21.6 \%) \\
5(9.8 \%) \\
4(7.8 \%) \\
2(3.9 \%) \\
8(15.7 \%)\end{array}$ \\
\hline
\end{tabular}

Tocilizumab was administered at a mean duration of 8 days since symptom onset and 2 days since hospitalization. At drug administration, 43 (84.3\%) patients were receiving non-invasive respiratory support (Noninvasive ventilation or high flow nasal cannula), $6(11.7 \%)$ patients were receiving conventional oxygen therapy (nasal prongs or venturi mask), and 2(3.9\%) were on invasive mechanical ventilation. All of the patients $(n=51)$ were administered tocilizumab based on clinical worsening $>24$ hours after steroid administration, out of which $32 / 46(69.5 \%)$ had severe disease in 
HRCT chest (CTSI>15) and 40/51(78.4\%) had raised or a significant increase in inflammatory markers at tocilizumab administration (table 2).

Table 2. Other clinical characteristics

\begin{tabular}{|c|c|}
\hline $\mathrm{SFR}(\mathrm{SPO} 2 / \mathrm{FiO} 2$ ratio) & $164.8 \pm 62(80-321)$ \\
\hline Fio2 requirement & $60 \%(28-100 \%)$ \\
\hline Number of days since symptom onset & $8(16-3)$ \\
\hline Number of days since hospitalization & $2(1-7)$ \\
\hline $\begin{array}{l}\text { Respiratory support at drug administration } \\
\text { Conventional oxygen support } \\
\text { Non-invasive ventilation } \\
\text { Invasive mechanical ventilation }\end{array}$ & $\begin{array}{l}6(11.7 \%) \\
43(84.3 \%) \\
2(3.9 \%)\end{array}$ \\
\hline $\begin{array}{l}\text { Raised inflammatory markers } \\
\text { radiological severity (CTSI }>15)\end{array}$ & $\begin{array}{l}40 / 51(78.4 \%) \\
32 / 46(69.5 \%)\end{array}$ \\
\hline $\begin{array}{l}\text { Average time for } \mathrm{O} 2 \text { independence after } \\
\text { tocilizumab(days) }\end{array}$ & $7.5(3-81)$ \\
\hline Patients discharged on Home Oxygen support & 8 (20\% of discharged patients) \\
\hline
\end{tabular}

The median baseline values of inflammatory markers (table 4) on the day of tocilizumab administration were CRP - $114.2 \mathrm{mg} / \mathrm{L}$, IL-6 -55.4 pg/ml, D dimer-401 ng/ml, Ferritin-541 ng/ml and Neutrophil to Lymphocyte Ratio -12.4. Out of these only CRP showed a significant decrease on day 3 and day 7 after tocilizumab administration. However, CRP significantly decreased in all patients irrespective of their outcome but the rest of the inflammatory markers showed a non-significant increasing trend in those who had a poorer outcome(figure 1). 
medRxiv preprint doi: https://doi.org/10.1101/2021.12.06.21266950; this version posted December 8, 2021. The copyright holder for this preprint (which was not certified by peer review) is the author/funder, who has granted medRxiv a license to display the preprint in It is made available under a CC-BY-NC-ND 4.0 International license

Figure 1: Trends in Inflammatory markers in discharged vs died patients
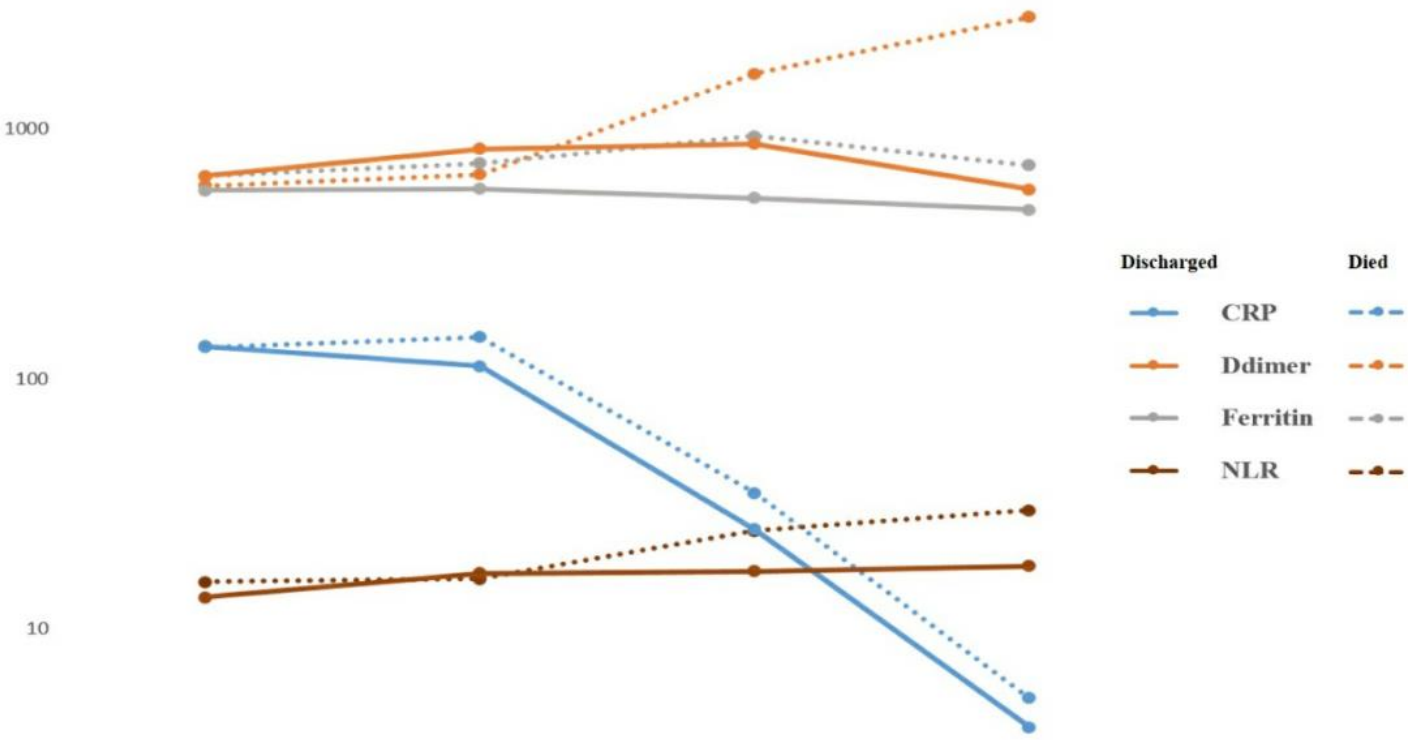

$\begin{array}{llll}\text { at admission } & \text { day } 0 & \text { day } 3\end{array}$

Following Tocilizumab administration (day 0, in figure 1), there was a significant decrease in oxygen requirement by day 3 and clinical improvement (by WHO clinical progression scale) by day 7(table 3). Average time to oxygen independence after giving the drug was 7.5 days. By day 28, 13/49(26.5\%) of the patients, who were on non-invasive oxygen support at the drug administration progressed to mechanical ventilation. Out of the 15 intubated patients, 5(33.3\%) were successfully weaned of the ventilator. The all cause mortality at day 28 was 10/51 $(19.6 \%)$ (table 4).

On bivariate analysis age (p-0.016), baseline $\mathrm{O} 2$ requirement (p-0.044), baseline D-dimer(p-0.039) and a history of CAD (p-0.002) was predictive of poor outcome at day 28 after tocilizumab administration, but up on logistic regression none of these factors were predictive. More than $2 / 3 \mathrm{rd}$ (78.4\%) of the patients received two doses, while $21.6 \%$ received only a single dose of tocilizumab. Overall 10(19.6\%) out of 51 patients had new 
medRxiv preprint doi: https://doi.org/10.1101/2021.12.06.21266950; this version posted December 8, 2021. The copyright holder for this preprint (which was not certified by peer review) is the author/funder, who has granted medRxiv a license to display the preprint in It is made available under a CC-BY-NC-ND 4.0 International license

onset of serious life threatening infections which includes: bloodstream infections (4), Ventilator associated pneumonia (4), Hospital acquired pneumonia (3) and empyema(1). Additionally, 5/51 patients had thrombocytopenia and 3/51 had pneumomediastenum or pneumothorax, 1/51 patient had colonic perforation and 1/51 patient had transaminitis (enzyme level $>5$ upper normal limit).

Table 3: O2 requirement and CPS (Clinical Progression Scale) progression after tocilizumab administration

\begin{tabular}{|l|l|l|l|l|l|}
\hline & Day 0 & Day 3 & Day 7 & Day 14 & Day28 \\
\hline $\begin{array}{l}\text { FiO2 [mean(min-max)] } \\
\text { P values with respect to day 0 }\end{array}$ & $\begin{array}{l}58 \pm 20(28- \\
100)\end{array}$ & $\begin{array}{l}51 \pm 22(21- \\
100) \\
\text { (0.042 }\end{array}$ & $\begin{array}{l}36 \pm 19(95-21) \\
<\mathbf{0 . 0 0 1}\end{array}$ & $\begin{array}{l}30 \pm 17(21- \\
95)\end{array}$ & $\begin{array}{l}26 \pm 14(21- \\
85) \\
<0.001\end{array}$ \\
\hline $\begin{array}{l}\text { P values for improvement in } \\
\text { CPS with respect to day 0 }\end{array}$ & & 0.569 & $\mathbf{0 . 0 0 1}$ & & $\mathbf{0 . 0 1}$ \\
& & & & $\mathbf{0 . 0 3 2}$ & \\
\hline
\end{tabular}

Table 4: Trend in Inflammatory markers

\begin{tabular}{|l|l|l|l|l|l|}
\hline & & & & P values \\
\hline CRP & Baseline & Day3 & Day & Baseline vs day3 & Baseline vs day 7 \\
\hline Ddimer & $114.2(5.2-344)$ & $23.6(0.3-102.81)$ & $3.6(0.4-13.7)$ & $<\mathbf{0 . 0 0 1}$ & \\
\hline Ferritin & $401(179-7430)$ & $435(142-8740)$ & $588(174-10810)$ & 0.432 & 0.747 \\
\hline NLR & $\begin{array}{l}541.6(19.4- \\
1606.7)\end{array}$ & $525.9(12.3-1379)$ & $471(19.3-1378)$ & 0.729 & \\
\hline IL6 & $12.4(0.2-63.4)$ & $13.6(0.27-111.9)$ & $17.5(1.44-56.7)$ & 0.393 & 0.096 \\
\hline
\end{tabular}

CRP-C-reactive protein, NLR-Neutrophil Lymphocyte Ratio, IL6-interleukin 6, LDH-Lactate dehydrogenase

Table 5: Primary outcome by day 28 
medRxiv preprint doi: https://doi.org/10.1101/2021.12.06.21266950; this version posted December 8, 2021. The copyright holder for this preprint (which was not certified by peer review) is the author/funder, who has granted medRxiv a license to display the preprint in It is made available under a CC-BY-NC-ND 4.0 International license .

\begin{tabular}{|l|l|}
\hline All cause mortality & $10 / 51(19.6 \%)$ \\
\hline Progression to mechanical ventilation & $13 / 49(26.5 \%)^{\#}$ \\
\hline & \\
\hline
\end{tabular}

\#2 patients who were already on the ventilator while receiving the drug were excluded

\section{Discussion}

Analysis of the above results indicates the usefulness of early and timely administration of tocilizumab in selected severe and critical COVID 19 patients who subsequently worsen or does not respond clinically with initial doses of steroids. This approach can result in significant decrease in clinical progression and $\mathrm{O} 2$ requirement by the end of first week of treatment. Most of the initial trials had predominately shown no benefit from IL-6 antagonists in COVID-19. ${ }^{[13-15]}$ This may be due to the inclusion of less severely ill patients and exclusion of patients receiving any form of respiratory support. Moreover, only minority of the patients in these trials received tocilizumab in combination with corticosteroids. Recently published study by the REMAP-CAP investigators $(\mathrm{n}=865)$, included more critical patients, with $70.3 \%$ patients on noninvasive ventilation respiratory support and $29 \%$ on invasive mechanical ventilation with a median $\mathrm{PaO} 2: \mathrm{FiO} 2$ ratio(PFR) value of $116.5^{[16]}$. The majority of patients (75.2\%) in this study also received glucocorticoids at enrollment or within the following 48 hours. The in-hospital mortality in this study was $27 \%$ with IL6 receptor antagonist group vs $36 \%$ in the control group and they concluded that, the treatment with the IL6 receptor antagonists tocilizumab and sarilumab improved outcomes, including survival. The RECOVERY trial is the largest study till date(n-4116) on tocilizumab in COVID-19. This trial also included critical COVID-19 patients (40.9\% on non-invasive and $13.6 \%$ on invasive respiratory support) and $82 \%$ of patients received steroids. This study showed an all cause mortality of $31 \%$ in tocilizumab group vs $35 \%$ in standard care group at day $28^{[17]}$. Further a recent metaanalysis combining all the RCTs till date on tocilizumab on COVID-19 showed a significant benefit in critically ill subgroup of patients who are admitted to ICU (all-cause mortality rate was $34.7 \%$ vs $39.6 \%)^{[12]}$. Compared to these previous studies, the 28 day mortality rate in our patients (19.6\%) was far less, this may be because we administered tocilizumab more selectively to ICU patients not responding to steroids 
medRxiv preprint doi: https://doi.org/10.1101/2021.12.06.21266950; this version posted December 8, 2021. The copyright holder for this preprint (which was not certified by peer review) is the author/funder, who has granted medRxiv a license to display the preprint in It is made available under a CC-BY-NC-ND 4.0 International license

rather than giving tocilizumab to all critically ill patients. This approach needs further validation with controlled trials. However, compared to the RECOVERY study, The progression to mechanical ventilation (26.5\%) was much larger in our patients, this may be because $84.9 \%$ of the patients in our group were already on non-invasive respiratory support on administration of tocilizumab as compared $41 \%$ in RECOVERY trial . We believe that our patients were more critical than the patients included in all the above studies due to the fact that steroid non responders were already having a poor clinical outcome. This is also reflected in the mean $\mathrm{SpO} 2 / \mathrm{FiO} 2$ (SFR) of 169 (corresponding to moderate ARDS) at the time of administration of tocilizumab in our patients . The SFR is a noninvasive surrogate of PFR with good sensitivity and specificity ${ }^{[18]}$.

We obtained good results, even though tocilizumab in all our patients was administered only on the basis of clinical worsening. This may be due to the following reasons: Firstly, Inflammatory markers like CRP and IL6 may be very sensitive, but their time to peak serum levels and half lives are not clear. Moreover, recent studies have shown that systemic levels of cytokines in Covid 19 may not be as high as seen with other causes of sepsis and acute respiratory distress syndrome ${ }^{[19]}$. It may be that local inflammation, as evidenced by respiratory dysfunction, is a more useful indicator of which patients will benefit from interleukin-6 inhibition. Secondly, the CRP levels also decrease significantly after starting steroids $^{[20,21]}$, which is also mirrored in our study, hence its level after initiating steroids may be unpredictable. Thirdly, as the clinical worsening occurs prior to radiological changes, we did not repeat chest radiology ( if the previous imaging was recent $(<24 \mathrm{hrs})$. Finally, the time lag to get these reports, would mean a further delay in the drug administration.

Data from our patients also shows that the trend of CRP is a poor prognostic marker for disease progression and outcome in those receiving tocilizumab and steroids. However, other inflammatory markers like Ddimer, ferritin and NLR can be valuable for the above purpose. This needs to be further confirmed in future trials. As compared to previous studies, the incidence of life threatening secondary infection(19.6\%) was high in our patient cohort and 18/51 (35.3\%) patients needed empirical antibiotic escalation at the discretion of the treating clinician. This was because combined use of steroids and tocilizumab make these patients vulnerable to severe secondary infection, but classical clinical manifestations of ongoing infections may be absent and laboratory chemical parameters may fail as diagnostic tools. 
Our study has some limitations. First, the descriptive nature of our study and absence of a comparator arm allows us to draw no meaningful conclusions from our data about the population and is the major limitation. Moreover, a comparator arm was difficult in the acute setting of pandemic. Secondly, the number of patients observed was very less, thus generalization of the data is not possible. Finally, because of the short follow up period, we were not able to assess the long term safety and adverse effects of tocilizumab.

\section{Conclusion}

To conclude, early and timely administration of tocilizumab only in selected severe and critical covid patients not responding to initial steroids appears to increase the survival. This needs to be further confirmed by randomised controlled trials. When given along with steroids, incidence of life threatening infections seems to increase, hence a high suspicion of secondary infection should be kept. 
medRxiv preprint doi: https://doi.org/10.1101/2021.12.06.21266950; this version posted December 8, 2021. The copyright holder for this preprint (which was not certified by peer review) is the author/funder, who has granted medRxiv a license to display the preprint in

It is made available under a CC-BY-NC-ND 4.0 International license .

\section{Reference's}

1 Huang C, Wang Y, Li X, Ren L, Zhao J, Hu Y, et al. Clinical features of patients infected with 2019 novel coronavirus in Wuhan, China. The Lancet. 2020;395(10223):497-506.

2 Gorbalenya AE, Baker SC, Baric RS, de Groot RJ, Drosten C, Gulyaeva AA, et al. The species Severe acute respiratory syndrome-related coronavirus: classifying 2019-nCoV and naming it SARS-CoV-2. Nature Microbiology. 2020;5(4):536-44.

3 Lai CC, Shih TP, Ko WC, Tang HJ, Hsueh PR. Severe acute respiratory syndrome coronavirus 2 (SARSCoV-2) and coronavirus disease-2019 (COVID-19): The epidemic and the challenges. Int J Antimicrob Agents. 2020;55(3):105924.

4 Zhou F, Yu T, Du R, Fan G, Liu Y, Liu Z, et al. Clinical course and risk factors for mortality of adult inpatients with COVID-19 in Wuhan, China: a retrospective cohort study. Lancet.

2020;395(10229):1054-62.

5 Wang Z, Yang B, Li Q, Wen L, Zhang R. Clinical Features of 69 Cases With Coronavirus Disease 2019 in Wuhan, China. Clinical infectious diseases : an official publication of the Infectious Diseases Society of America. 2020;71(15):769-77.

6 Horby P, Lim WS, Emberson JR, Mafham M, Bell JL, Linsell L, et al. Dexamethasone in Hospitalized Patients with Covid-19. The New England journal of medicine. 2021;384(8):693-704.

7 Group TWREAfC-TW. Association Between Administration of Systemic Corticosteroids and Mortality Among Critically III Patients With COVID-19: A Meta-analysis. JAMA. 2020;324(13):1330-41.

8 Jeronimo CMP, Farias MEL, Val FFA, Sampaio VS, Alexandre MAA, Melo GC, et al.

Methylprednisolone as Adjunctive Therapy for Patients Hospitalized With Coronavirus Disease 2019

(COVID-19; Metcovid): A Randomized, Double-blind, Phase IIb, Placebo-controlled Trial. Clinical infectious diseases : an official publication of the Infectious Diseases Society of America.

2021;72(9):e373-e81.

9 Tomazini BM, Maia IS, Cavalcanti AB, Berwanger O, Rosa RG, Veiga VC, et al. Effect of Dexamethasone on Days Alive and Ventilator-Free in Patients With Moderate or Severe Acute Respiratory Distress Syndrome and COVID-19: The CoDEX Randomized Clinical Trial. JAMA. 2020;324(13):1307-16.

10 Yoshikawa T, Hill T, Li K, Peters CJ, Tseng CT. Severe acute respiratory syndrome (SARS) coronavirus-induced lung epithelial cytokines exacerbate SARS pathogenesis by modulating intrinsic functions of monocyte-derived macrophages and dendritic cells. Journal of virology. 2009;83(7):303948.

11 Romagnoli S, Peris A, Gaudio ARD, Geppetti P. SARS-CoV-2 and COVID-19: From the Bench to the Bedside. Physiological Reviews. 2020;100(4):1455-66.

12 Snow TAC, Saleem N, Ambler G, Nastouli E, Singer M, Arulkumaran N. Tocilizumab in COVID-19: a meta-analysis, trial sequential analysis, and meta-regression of randomized-controlled trials. Intensive Care Med. 2021;47(6):641-52.

13 Stone JH, Frigault MJ, Serling-Boyd NJ, Fernandes AD, Harvey L, Foulkes AS, et al. Efficacy of Tocilizumab in Patients Hospitalized with Covid-19. The New England journal of medicine. 2020;383(24):2333-44.

14 Hermine O, Mariette X, Tharaux P-L, Resche-Rigon M, Porcher R, Ravaud P, et al. Effect of Tocilizumab vs Usual Care in Adults Hospitalized With COVID-19 and Moderate or Severe Pneumonia: A Randomized Clinical Trial. JAMA Internal Medicine. 2021;181(1):32-40.

15 Salvarani C, Dolci G, Massari M, Merlo DF, Cavuto S, Savoldi L, et al. Effect of Tocilizumab vs Standard Care on Clinical Worsening in Patients Hospitalized With COVID-19 Pneumonia: A

Randomized Clinical Trial. JAMA Intern Med. 2021;181(1):24-31.

16 Interleukin-6 Receptor Antagonists in Critically III Patients with Covid-19. New England Journal of Medicine. 2021;384(16):1491-502.

17 Tocilizumab in patients admitted to hospital with COVID-19 (RECOVERY): a randomised, controlled, open-label, platform trial. Lancet. 2021;397(10285):1637-45. 
medRxiv preprint doi: https://doi.org/10.1101/2021.12.06.21266950; this version posted December 8, 2021. The copyright holder for this preprint (which was not certified by peer review) is the author/funder, who has granted medRxiv a license to display the preprint in It is made available under a CC-BY-NC-ND 4.0 International license.

18 Rice TW, Wheeler AP, Bernard GR, Hayden DL, Schoenfeld DA, Ware LB. Comparison of the $\mathrm{SpO} 2 / \mathrm{FIO} 2$ ratio and the $\mathrm{PaO} 2 / \mathrm{FIO} 2$ ratio in patients with acute lung injury or ARDS. Chest. 2007;132(2):410-7.

19 Sinha P, Calfee CS, Cherian S, Brealey D, Cutler S, King C, et al. Prevalence of phenotypes of acute respiratory distress syndrome in critically ill patients with COVID-19: a prospective observational study. The Lancet Respiratory medicine. 2020;8(12):1209-18.

20 Perren A, Cerutti B, Lepori M, Senn V, Capelli B, Duchini F, et al. Influence of steroids on procalcitonin and $\mathrm{C}$-reactive protein in patients with COPD and community-acquired pneumonia. Infection. 2008;36(2):163-6.

21 Mysler E, Psioni C, Tate P, Tate G. Influence of corticosteroids on C-reactive protein in patients with rheumatoid arthritis. Arthritis Res Ther. 2004;6(3):57. 